\title{
Una causa subdiagnosticada de fiebre recurrente: enfermedad relacionada al calor
}

\author{
Heat-related illness
}

$S^{\text {ini }}$ eñor Editor: En nuestro país no existe información sobre la enfermedad relacionada al calor, probablemente por tener clima templado, sin grandes alzas térmicas. Debido al calentamiento global de la tierra, se están generando ondas de calor (que se definen como 3 o más días consecutivos con temperatura ambiental $>32,2^{\circ} \mathrm{C}$ ), en zonas de clima templado. Es probable, entonces, que observemos un aumento de esta patología. Como referencia, en Estados Unidos se estima una incidencia de 17,6 a 26,5 casos por 100.000 de habitantes $^{1}$. Estas cifras llegan a entre 22 y 250 por 100.000 en países cálidos como Arabia Saudita, con una mortalidad de 50\% y con varios miles de muertos por año debido a esta causa ${ }^{1}$. La mayonía de las personas afectadas por la forma más grave y fatal ("golpe de calor") son jóvenes o adultos mayores debilitados, discapacitados, pobres, socialmente aislados, con poco acceso a hidratación por su condición neurológica de base o por no tener acceso a sistemas de climatización. Igualmente son un grupo de riesgo los confinados en cama, desnutridos, con uso crónico de tranquilizantes, neurolépticos, antidepresivos tricíclicos, antihistamínicos, antiparkinsonianos, hipnóticos, alcohol y efedrina ${ }^{1-3}$. La mortalidad de la forma más grave alcanza a $70 \%$; la mayonía de las muertes ocumen cuando el tratamiento se retrasa más de $2 \mathrm{~h}$.

La forma más benigna de este cuadro, pero que puede evolucionar a golpe de calor, es "agotamiento por calor" y es más frecuente, con 450 a 1.800 casos por 100.000 habitantes $^{1}$. Presentamos un paciente con importantes dificultades diagnósticas de la causa de su cuadro febril y que correspondió a este síndrome.

\section{Caso CĹ́nico}

Varón de 23 años, portador de una parálisis cerebral coreoatetósica secundaria a hipoxia perinatal, quien recibía fenobarbital $75 \mathrm{mg} /$ día por epilepsia ya inactiva desde la infancia y loratadina por alergia respiratoria. Ingresó al Centro de Pacientes Críticos debido a fiebre recurrente sin causa aclarada. Ingresó con $\mathrm{t}^{\circ}=38,5^{\circ} \mathrm{C}$, deshidratado, somnoliento, sin signología meníngea ni claros signos de foco infeccioso. Los estudios realizados: hemograma, VHS, PCR, hemocultivos, urocultivos, Rx de tórax, scanner de tórax, abdomen y pelvis fueron normales. Los electrolitos plasmáticos mostraron una leve hipernatremia de $149 \mathrm{mEq} / \mathrm{l}$. La fiebre y compromiso del estado general remitieron a los pocos días, con adecuada hidratación y manejo de la temperatura ambiental. Se realizó una resonancia magnética cerebral que mostró marcada abiotrofia cerebral, de acuerdo a su daño previo, y lesiones hiperintensas en las secuencias T1 y T2 en regiones talámicas paraventriculares, probablemente de origen isquémicohemorrágico y de tipo secuelar. Estas imágenes han sido descritas recientemente como características del espectro de enfermedades relacionadas al calor ${ }^{4}$.

El cuadro clínico del paciente, según su madre (quien es enfermera), se ha repetido al menos 810 veces, motivando hospitalizaciones para estudio e hidratación, específicamente en los meses de mayor calor, sin haber recibido diagnóstico preciso. En una ocasión presentó incluso una rabdomiolisis. El paciente vive en un lugar muy 
caluroso y sin aire acondicionado. Cada vez que presentaba alzas térmicas (muy rara vez alcanzando $40^{\circ}$ ) no respondía al uso de antipiréticos, siendo lo más útil el uso de solución hidratante intravenosa fría.

El agotamiento por calor es un síndrome agudo con hipertermia causada por deshidratación, ocurre cuando el cuerpo no puede disipar adecuadamente el calor debido a condiciones ambientales muy calurosas o excesiva producción endógena de calor. Puede progresar a golpe de calor cuando los mecanismos termorreguladores son sobrepasados y fallan. Si esto ocurre, el desarrollo de hipertermia se acelera, con falla orgánica múltiple y coagulación intravascular diseminada.

Los síntomas de agotamiento por calor son inespecíficos y pueden ser insidiosos, semejando una enfermedad viral. Hay fatiga, debilidad, náuseas y vómitos, mareos, calambres musculares y mialgias, irritabilidad. En el examen físico destacan astenia, cambios ortostáticos de la presión arterial, piloerección, taquicardia, la temperatura usualmente es menor de $41^{\circ} \mathrm{C}$. Se habla de "golpe de calor" cuando se observa una temperatura central (rectal) mayor de $40,6^{\circ} \mathrm{C}$ y disfunción importante del sistema nervioso central como delirio, convulsiones o coma ${ }^{1-3}$. Existe una forma clásica, que ocurre en personas debilitadas o con los factores de riesgo señalados y la forma relacionada al ejercicio que se observa en individuos físicamente muy activos 0 atletas ${ }^{1-3}$. El que algunas personas desarrollen estas complicaciones o presenten agotamiento por calor y no golpe de calor, está probablemente relacionado a polimorfismos genéticos relacionados a genes que controlan la actividad de citoquinas, proteínas de la coagulación y proteínas involucradas en la adap-

\section{REFERENCIAS}

1. Bouchama A, Knochel J. Heat Stroke. N Engl J Med 2002; 346: 1978-88.

2. Yeo TP. Heat Stroke: a comprehensive review. AACN 2004; 15: 280-93.

3. Duthie D. Heat-related illness. Lancet 1998; 352: 1329-30. tación al calor llamadas "proteínas de choque térmico". La más importante es la proteína de resistencia al calor 72 , que se acumula en el cerebro, produciendo un estado transitorio de hipotensión e isquemia, jugando un rol muy importante en la capacidad de aclimatización ${ }^{1,2}$. Cuando la síntesis de este tipo de proteínas está alterada, por ejemplo por polimorfismos genéticos, las células se vuelven en extremadamente susceptibles al estrés por calor. Por lo tanto, algunas personas pueden ser más susceptibles genéticamente a desarrollar "agotamiento por calor" o "golpe de calor" debido a la incapacidad de protegerse a través de la producción de estas proteínas de resistencia al calor ${ }^{1,2}$.

El manejo preventivo de esta condición es evitar condiciones ambientales con calor excesivo, uso adecuado de climatización, ingesta adecuada de líquidos y, una vez ya presentado, generosa hidratación oral o intravenosa con solución salina, con la mitad de las pérdidas de volumen repuestas en las primeras 3-6 h y el resto en las próximas 6$9 \mathrm{~h}$. Uso de compresas frías y no antipiréticos, los que son ineficaces en esta condición, ya que el aumento de temperatura no se debe a un aumento del nivel hipotalámico. Los salicilatos pueden agravar coagulopatías y el paracetamol agravar el potencial daño hepático ${ }^{1-3}$.

En nuestro medio debe existir mayor conocimiento de la existencia de esta patología tanto a nivel hospitalario, como en los servicios de urgencia y atención ambulatoria, ya que un diagnóstico y tratamiento precoz puede evitar un desenlace fatal.

\section{Marcelo Miranda C y Sergio Valdés Jiménez.}

Unidad de Neurología y Centro de Pacientes Críticos, Clínica Las Condes, Santiago, Chile.

4. McLaughun CT, Kaue A, Auber A. MR imaging of heat stroke: external capsule and thalamic T1 shortening and cerebellar injury. AJNR 2003; 24: 1372-5.

Correspondencia a: Marcelo Miranda. Lo Fontecilla 441, Las Condes. Fono Fax 3650028. E-mail: marcelomiranda@terra.cl. 